Cómo citar este artículo en Chicago: Álvarez Lobato, Carmen. "Una mirada a la infancia: el espanto social en Las cosas que perdimos en el fuego, de Mariana Enríquez”. Escritos 30, no. 64 (2022): 60-76. doi: http://doi.org/10.18566/escr.v30n64.a04

\title{
Una mirada a la infancia: el espanto social en Las cosas que perdimos en el fuego, de Mariana Enríquez
}

\author{
A look at childhood: the social fear in The things we lost in the fire, \\ by Mariana Enríquez
}

\author{
Carmen Álvarez Lobato ${ }^{1}$
}

\begin{abstract}
RESUMEN
Este artículo analiza cinco cuentos del volumen Las cosas que perdimos en el fuego, de Mariana Enríquez: "El chico sucio", "La casa de Adela", "Pablito clavó un clavito: una evocación del Petiso Orejudo", "El patio del vecino" y "Bajo el agua negra", donde la autora reescribe el tema de la infancia. Esta reescritura está lejos de una visión idílica, ya que se trata de la problematización de la infancia moderna; los protagonistas de estos relatos son niños que violentan o son violentados y que, simbólicamente, proponen la ausencia de futuro y esperanza. Para el análisis de estos cuentos utilizo categorías propias de la estética del grotesco, ya que los conceptos propuestos por Wolfgang Kayser en Lo grotesco. Su configuración en pintura y literatura me permiten trascender las convenciones del terror, género con el que normalmente se asocia la obra de Enríquez. Más que los componentes sobrenaturales propios del terror o lo fantástico subrayo en este artículo la crítica social y la noción del vacío que conforman la poética de la autora argentina, de ahí que proponga la categoría del "espanto social". El mundo que presenta Mariana Enríquez es uno sombrío y desarticulado, sin fuerzas extrañas a las que culpar, que nos obliga a mirar la realidad de nuestra sociedad moderna.
\end{abstract}

Palabras clave: Mariana Enríquez; Infancia; Espanto social; Grotesco; Modernidad; Las cosas que perdimos en el fuego.

\section{ABSTRACT}

This article analyzes five stories from the volume Las cosas que perdimos en el fuego (or The things we lost in the fire), by Mariana Enríquez: The Dirty Boy, Adela's House, Pablito nailed a little nail: an evocation of Big-Eared Petiso, My neighbor's yard and Under the black water, where the author rewrites the theme of childhood. This rewriting is far from an idyllic vision, since it deals with the problematization of modern childhood; the main

1 Profesora-investigadora adscrita a la Facultad de Humanidades de la Universidad Autónoma del Estado de México. Doctora en Literatura Hispánica por El Colegio de México. Integrante del cuerpo académico "Literatura y pensamiento crítico" y miembro del Sistema Nacional de Investigadores. Correo electrónico: mcalvarezl@uaemex.mx. 
characters of these stories are children who violate or are violated and who, symbolically, propose the absence of future and hope. For the analysis of these stories, I use categories typical of the aesthetics of the grotesque, from the concepts proposed by Wolfgang Kayser in The Grotesque. Its configuration in painting and literature allows me to transcend the conventions of terror, a genre with which Enríquez's work is generally associated. More than the supernatural components typical of terror or the fantastic, I emphasize in this article the social criticism and the notion of emptiness that make up the poetics of the Argentine author, which is why she proposes the category of "social horror". The world that Mariana Enríquez presents is a gloomy and disjointed one, with no foreign forces to blame, that forces us to look at the reality of our modern society.

Keywords: Mariana Enríquez, Childhood; Social Fright, Grotesque, Modernity; Las cosas que perdimos en el fuego.

$\mathrm{M}$ ariana Enríquez, la premiada y exitosa escritora argentina, suma ya, desde su primera novela Bajar es lo peor (1995), una decena de textos narrativos; su obra, consistente y madura, ha sido celebrada por los lectores y catalogada por la crítica especializada como perteneciente al género del terror, lo fantástico o lo gótico. La misma autora ha defendido su predilección por el género del terror, aunque consciente de que en su obra debía realizar una actualización del género, incluir una suerte de perspectiva argentina, incluso latinoamericana:

No podía hacer un terror relacionado con los monstruos tradicionales, el castillo, todo el imaginario del gótico que ya estaba codificado. Tenía que hacer un terror nacional, argentino, latinoamericano. En esa operación, encontré las cosas propias, la religiosidad pagana argentina que tiene muchos aspectos siniestros y ciertos aspectos de la política que son fácilmente llevados al terror. Quiero decir, una oscuridad relacionada con lo político y lo social, pero respetando algunas cosas del género. ${ }^{2}$

La obra de Enríquez resulta perturbadora por los temas tratados: los problemas de la adolescencia, la locura, las drogas, la violencia de género, el infanticidio, la dictadura, etc., temas que múltiples veces trascienden las convenciones del terror o lo fantástico. Enríquez no niega su filiación al género, pero lo ve como un "marco", ya que propone también ser leída desde una perspectiva más amplia que para ella estaría representada por lo extraño o lo weird:

[El terror] es sencillamente mi género favorito de siempre [...] Que esté bastante al margen también me atrae, que se lo considere "menor" hace que escribir en el marco del género de terror sea un poco secreto y esa situación relativamente oscura determina que se puedan encontrar en el género textos muy estimulantes: no estar en el centro te libera de ciertas miradas "importantes" y otras pomposidades. Yo los llamo cuentos "extraños": los escritores anglosajones últimamente los llaman "new weird" y me parece una definición más amplia y adecuada. ${ }^{3}$

La actualización del género que realiza Mariana Enríquez implica también una transgresión a este, un acercamiento a la crítica social y política en que los elementos sobrenaturales de sus relatos resultan

2 Verónica Boix, “Mariana Enríquez: Simpatía por los demonios”, Clarín, Revista Ñ, 31 de enero de 2020, https://www. clarin.com/revista-enie/simpatia-demonios_0_vE7c0RiW.html.

3 Leonardo Martinelli, “Mariana Enríquez: El fuego camina conmigo”, El Planeta Urbano, 21 de agosto de 2020, https:// elplanetaurbano.com/2020/08/mariana-enriquez-el-fuego-camina-conmigo/. 
secundarios o son inexistentes. ${ }^{4}$ La autora retrata la profunda violencia e indiferencia que habita en todas las células de la sociedad argentina, desde el Estado y la Iglesia, hasta la escuela, el barrio y la familia. Saca a los personajes marginales de los bordes de la sociedad y los pone en el centro de sus relatos, nos obliga a mirarlos muy de cerca y los vemos como monstruos o deformes. Pero el monstruo no necesariamente acusa una deformidad física o moral, su principal función es mostrar ${ }^{5}$ lo ajeno, lo distinto. Saber que "al lado" de nosotros, quizá, dentro de nosotros mismos, habita lo otro, probablemente sea lo que provoque el miedo que se asocia usualmente al terror, pero que no es exclusivo de este. También la esfera histórica, política o social nos asusta al saber que la "realidad" es inestable y que las certezas son solo una apariencia. Este "darnos cuenta" que implica posar sobre nuestro mundo una mirada desenajenada, asumir nuestras contradicciones, cuestionar la realidad "ideal" del hombre y sus construcciones es lo que provoca el "espanto social", hijo del tiempo histórico.

Esta mirada que se posa en los "distintos" es notoria en los cuentos de Las cosas que perdimos en el fuego (2016). Doce cuentos perturbadores que tienen como protagonistas adolescentes sin rumbo, chicos sucios, mujeres deformadas, pequeños asesinos y parejas disfuncionales que deambulan en las zonas marginales de la ciudad o que dan cuenta de los problemas del centro, que no son nuevos, pero que las diferentes formas del poder han negado sistemáticamente con la intención de invisibilizarlos.

Entre la variedad de temas que ofrece este volumen de cuentos, abordaré uno que me parece significativo y que es tratado de manera reiterada en la obra de Enríquez: el de la reescritura de la infancia, y que está lejos de una visión idílica. Se trata de cinco cuentos: "El chico sucio", "La casa de Adela", "Pablito clavó un clavito: una evocación del Petiso Orejudo", "El patio del vecino" y "Bajo el agua negra", relatos cuyos protagonistas son niños que violentan o son violentados y que, simbólicamente, proponen la ausencia de futuro y esperanza. Para el análisis de estos relatos, utilizaré categorías propias de la estética del grotesco, no porque desee agregar una etiqueta más a la obra de Mariana Enríquez, sino porque considero que el grotesco, estética que destaca una mezcla de dominios, una estructura ambivalente y un efecto de extrañeza ante variados procesos de disolución: "la mezcla de dominios para nosotros separados, la anulación de la estática, la pérdida de la identidad, la deformación de las proporciones 'naturales' [...] la anulación de la categoría de cosa, la destrucción de concepto de personalidad, la aniquilación del orden histórico", ${ }^{6}$ bien puede relacionarse con la estética weird de la que habla la autora. Más aún, la "vinculación secreta y aterradora entre lo fantástico y nuestro mundo", p propia del grotesco y el efecto de estremecimiento al comprobar que nuestro mundo no es "nada más que apariencia [...] no se trata del miedo a la muerte sino de la angustia ante la vida. Corresponde a la estructura de lo grotesco el que nos fallen las categorías de nuestra orientación en el mundo", como el efecto de sentido que otorga la reescritura de la infancia que propone la autora argentina.

4 En todo caso, para Enríquez, el terror no debe desvincularse de la realidad: "Pensar en una novela de terror despegada de la realidad es muy difícil. Los escritores de género más clásicos, como Lovecraft, hacen que sus personajes circulen por lugares reales y normales. El terror, para dar miedo, necesita emanar de la realidad". Martinelli, "Mariana Enríquez".

5 Una primera definición de monstruo indica: “Monstro [...] Mostrar, indicar, señalar”. Diccionario de la lengua latina, s.v. "Monstro".

6 Wolfgang Kayser, Lo grotesco: Su configuración en pintura y literatura (Buenos Aires: Nova, 1964), 225.

7 Kayser, Lo grotesco, 147.

8 Kayser, Lo grotesco, 225. 
El tema de la infancia aparece de inmediato en el volumen de Las cosas que perdimos en el fuego desde lo paratextual. Un primer epígrafe de Emily Brontë, tomado de Cumbres borrascosas, anuncia la infancia salvaje: "I wish I were a girl again, half-savage and hardy, and free". Además de la lectura de Cumbres borrascosas que, afirma Enríquez, la marcó desde su infancia, la autora establece en su volumen de cuentos un diálogo con otra de sus figuras tutelares, Silvina Ocampo, tan bien interpretada en La hermana menor: Un retrato de Silvina Ocampo: "Gran parte de la literatura de Silvina Ocampo parece contenida ahí: en la infancia [...] De ahí parecen venir sus cuentos protagonizados por niños crueles, niños asesinos, niños asesinados, niños suicidas, niños abusados, niños pirómanos, niños perversos, niños que no quieren crecer, niños que nacen viejos, niñas brujas, niñas videntes".

No es raro, entonces, que, en estos cinco relatos, los protagonistas sean los niños, los más pequeños, los más vulnerables y los más invisibles de una sociedad. La definición de infancia en latín, incluso, remite a la ausencia de raciocinio y destaca el carácter prelógico de la niñez: "Infantia [...] ignorancia en el hablar, falta de explicación [...] edad tierna de los irracionales". ${ }^{10}$

La infancia como etapa dulce de la vida es un concepto moderno. Se pone cierta atención en la niñez en el siglo XVIII, siglo que coincide con la nueva estética romántica que no tarda en idealizar a los infantes precisamente por la ausencia de razón que los caracteriza y que los acerca al mundo mágico y a la inocencia primitiva; Rafael Argullol resume bien esta idealización con respecto a los románticos ingleses y alemanes (escritores con los que dialoga Brontë en su obra): "El niño es un ser divino [...] La coerción de la ley y del destino no le andan manoseando; en el niño solo hay libertad, en él hay paz; aún no se ha destrozado consigo mismo. Hay en él riqueza; no conoce su corazón la mezquindad de la vida. Es inmortal, pues nada sabe de la muerte". ${ }^{11}$ Idealización que es posteriormente retomada por el modernismo, en tanto observa la infancia como etapa de educación y posibilidad de futuro, y por la vanguardia: ya en el siglo XX el dadaísmo y el surrealismo, que festejan el arte ilógico, maravilloso e imaginativo, el asalto al realismo y la razón, retoman el mundo onírico, la locura, la magia, el juego y la infancia como la base de su poesía. Así, se sustenta en la época moderna, ya no solo literariamente, sino culturalmente, la imagen de la infancia como una etapa idílica, su pérdida como motivo de tristeza y el anhelo por recobrarla como un regreso a la edad de oro: inocencia, placer, juego y felicidad. Otras disciplinas, sin embargo, como la antropología o el psicoanálisis, despojan la niñez de ese carácter idílico y le devuelven su condición primitiva y transgresora:

Los niños eran seres humanos aún libres [...] Como en la realidad ningún niño respondía a tales exigencias, los padres tenían que preguntarse [...] por qué razones sus hijos presentaban rasgos que no correspondían muy bien al carácter angelical atribuido como norma a los niños. Tal vez el hecho de que los castigos y las medidas conducentes a disciplinar a los niños [...] resultasen particularmente severos se deba justamente

9 Mariana Enríquez, La hermana menor: Un retrato de Silvina Ocampo (Santiago de Chile: Universidad Diego Portales, 2014), 17.

10 Diccionario de la lengua latina, s.v. "Infantia".

11 Rafael Argullol, El héroe y el único: El espíritu trágico del romanticismo (Madrid: Taurus, 1984), 58. Por eso, en el Romanticismo, surge también la literatura creada ex profeso para niños, por ejemplo, desde los cuentos de Hoffmann; posteriormente, la literatura infantil se extiende por toda Europa. Estos relatos infantiles nacen con una intención moralizante, pero dejan ver el sustrato penoso de la infancia desde la violencia simbólica que reescriben: ventas, encierros, abandonos, abusos y orfandades. 
a esas discrepancias entre un ideal de los niños socialmente aprobado, pero totalmente fantasioso, por un lado, y su verdadera naturaleza, nada angelical, casi animal, pero en todo caso apasionada y salvaje, por el otro. ${ }^{12}$

Avanzado el tiempo, el siglo XXI muestra el carácter ambivalente de la infancia que va de la más pura inocencia (libertad, posibilidad de cambio y esperanza) a su condición salvaje e, incluso, sórdida (narcisismo, primitivismo, carencia de razón). Por otro lado, el tópico de los miedos infantiles primarios (el abandono, la pérdida o el maltrato) ha sido usado como mecanismo del terror y del horror de manera recurrente, pero llama la atención que en estos relatos de Enríquez los niños no son los que tienen miedo, sino los que lo provocan. Así, el chico sucio se enfrenta de manera natural a la realidad de su sociedad y a las duras calles asfaltadas con los pies desnudos; la pequeña Adela, sin miedo, se enfrenta a la casa inquietante que termina por devorarla; el Petiso Orejudo solo siente un impulso primitivo por asesinar; el niño gato de "El patio del vecino" no desea ser salvado de su encierro, sino que él mismo encierra y devora. Los chicos de "Bajo el agua negra", deformados o asesinados por el "progreso", insisten en mostrarse, en ocupar un lugar en el mundo, al menos en fungir como recordatorio de la violencia de la que son víctimas.

Si hay miedo en los relatos de Enríquez, es en la mirada adulta, en el orden, en los personajes de clase media que parten del concepto de la infancia idílica y que son enfrentados a esta niñez deformada y sórdida. Pero creo que, más que miedo, el efecto de estos relatos es uno de perplejidad y de extrañeza por la súbita irrupción de un momento significativo que desestructura la "estabilidad" del mundo conocido. En dicho momento, la mirada adulta alcanza a entender que el mundo armónico en el que supuestamente se sustenta la civilización no lo es tanto, que sus conceptos de orden, educación y bienestar resultan absurdos ante esta desazón que no pertenece al terreno de lo mágico o de lo sobrenatural, sino al de lo cotidiano y familiar, a la pesadilla de la historia. Por eso, los personajes y narradores adultos finalizan sus relatos con estupor, con los ojos bien abiertos observando el mundo, su mundo, transformado, como bien ha señalado la crítica:

Sin embargo, en cada historia el verosímil estalla y el efecto de terror se hace carne en esa mezcla indiferenciada, la unión de lo que debe permanecer separado: lo real y lo sobrenatural; la clase media y sus otros. Mariana Enríquez explora nuestros miedos en todas sus dimensiones, el terror metafísico, pero también aquel otro, el que el manual del buen progre impide confesar. ${ }^{13}$

Así, en el relato que abre el volumen de cuentos, "El chico sucio", Enríquez marca un escenario que se repetirá a lo largo de los demás relatos: los barrios marginales de Buenos Aires. En este caso, se trata del barrio Constitución, zona que gozó de glorias pasadas, "zona donde vivía la aristocracia porteña"14 en el siglo XIX, pero que en el momento de la narración se ha convertido en un barrio abandonado y peligroso donde abundan los menesterosos, travestis, prostitutas, drogadictos y criminales. La narradora personaje, una joven diseñadora que vive en la casona heredada por sus padres, más por capricho que por necesidad, que no pertenece a ese mundo lumpen y que tiene un esquema de valores clasemedieros regidos por las posibilidades sociales de la educación, el bienestar, la limpieza y el orden: “de las habitaciones frescas, de

12 Norbert Elias, La civilización de los padres y otros ensayos (Bogotá: Norma, 1998), 417.

13 María Celeste Cabral, "Frente a todos nuestros miedos: La única mujer rebelde es la que arde", Memoria Académica 7, no. 13 (2016): 125-128, http://sedici.unlp.edu.ar/handle/10915/57110.

14 Mariana Enríquez, Las cosas que perdimos en el fuego (Barcelona: Anagrama, 2016), 10. 
la escalera de madera, del patio interno, de los azulejos antiguos, de los techos altos", ${ }^{15}$ debe enfrentarse al conflicto social, a su barrio transformado desde la figura de un par de menesterosos: una joven drogadicta embarazada y su pequeño hijo de cinco años, el chico sucio, quienes viven a la intemperie a las afueras de un edificio abandonado enfrente de su casa.

El niño sobrevive malamente vendiendo estampitas de un santo en el subterráneo bonaerense y en algún momento tiene un encuentro fortuito con la narradora: el mundo de la clase media se toca con el mundo marginal sin que uno y otro alcancen a entenderse. Ocurre un encuentro más cuando una noche el niño toca desesperadamente a la puerta de la joven protagonista, él tiene hambre, su madre ha desaparecido y la narradora le ofrece algo de cenar. Le invita después de la cena, aunque ya es noche cerrada, un helado del establecimiento cercano; la chica comprueba el abismo que la separa del niño: camina descalzo, es silencioso, entiende el mundo: "Tuve ganas de sacudirlo y enseguida me avergoncé. Necesitaba que lo ayudase; no tenía por qué saciar mi curiosidad morbosa. Y, sin embargo, algo en su silencio me enojaba. Quería que fuera un chico amable y encantador, no este chico hosco y sucio". ${ }^{16}$ Se confronta el esquema de valores de la protagonista: la idea de un helado, que parecería adecuada para agasajar a un niño clasemediero, resulta, en este contexto, absurda. El niño representa, además, un submundo inserto en los márgenes de la civilización urbana, el del desorden no solo de la pobreza, sino del primitivismo de rituales religiosos prohibidos y alienantes representados no ya por las estampitas de san Expedito que vende el niño, sino por los altares a san Gauchito Gil que invaden la avenida: "las tres cuadras estaban casi vacías de travestis pero estaban llenas de altares. Recordé lo que se celebraba: era el 8 de enero, el día de Gauchito Gil. Un santo popular de la provincia de Corrientes que se venera en todo el país y especialmente en los barrios pobres", ${ }_{17}$ que, para la protagonista, reviste un carácter popular, incluso gracioso, que relata al niño desde su posición distanciada del conocimiento. Él está al tanto y debe corregirla: "El gaucho es bueno [...] pero el otro no". ${ }^{18}$ El "otro" es san La Muerte, "el santito esqueleto con sus velas rojas y negras". ${ }^{19}$ Este otro culto, aún más marginal, derivado de la iconografía cristiana de la Edad Media y el Renacimiento, terminó por convertirse en tierras de América Latina en un culto alterno en torno al "santo" apócrifo, bien aceptado por los grupos urbanos marginales hasta convertirse en santo tutelar de los criminales con rituales poco convencionales de por medio.

Finalmente, el niño y la narradora regresan a su barrio, él a la intemperie y a una madre furiosa que amenaza a la protagonista, ella al confort de su casa. Al día siguiente, madre e hijo han desaparecido. Sobreviene, entonces, en el barrio, un hecho horrible: aparece un niño muerto y torturado; las imágenes que presenta Enríquez son chocantes y excesivas, seguramente cercanas al carácter morboso de los periódicos de nota roja: "Degollado. Habían colocado la cabeza a un costado del cuerpo [...] se sabía que la cabeza estaba pelada hasta el hueso y que no se había encontrado pelo en la zona. También, que los párpados estaban cosidos y la lengua mordida, no se sabía si por el propio chico muerto o [...] por los dientes de otra persona". ${ }^{20}$

15 Enríquez, Las cosas que perdimos en el fuego, 33.

16 Enríquez, Las cosas que perdimos en el fuego, 16.

17 Enríquez, Las cosas que perdimos en el fuego, 17.

18 Enríquez, Las cosas que perdimos en el fuego, 18.

19 Enríquez, Las cosas que perdimos en el fuego, 18.

20 Enríquez, Las cosas que perdimos en el fuego, 22. 
Agobiada, la protagonista cree que se trata del niño conocido del que no sabe su nombre, se arrepiente de no haber hecho algo más por el chico para sacarlo de ese terrible destino, su deseo raya en el absurdo: "comprarle un patito y esos palitos para hacer burbujas y que jugara. Tranquilamente podría haberlo bañado y después nos íbamos a tomar el helado [...] o ayudar a que entrara en adopción con una familia que lo quisiera", ${ }^{21}$ esto es, conferir los valores de educación y limpieza que le corresponden a ella y que resultan tan ajenos al pequeño. Después de algunas investigaciones por la policía se sabe finalmente que este asesinato fue un probable rito a san La Muerte, pero de otro niño, de otro barrio, de otro aspecto: "un gordito con hoyuelos y pelo bien peinado"22 y con un nombre, Nachito, no del chico sucio. En las escenas finales del relato, la narradora se topa con la adolescente madre del chico, la increpa, le pregunta por su hijo; finalmente, la madre reconoce haber entregado, al pequeño de cinco años y al bebé recién nacido, a algún culto: "Y a éste también se los di. Se los prometí a los dos". ${ }^{23}$ Se sabe, pues, que efectivamente el pequeño niño y su hermano han sido entregados a los abismos de la ignorancia y la superstición, quizá, como objetos vendibles y tasables. En efecto, se ha descubierto un terrible crimen, pero de un niño de otra clase social y de otro barrio; para los pequeños chicos sin nombre y sin futuro, para los desclasados de siempre que no alcanzan ni una mención en la nota roja o en los programas sensacionalistas, solo queda el silencio.

No queda al final sino el reconocimiento de la protagonista de la realidad que la rodea, del abismo que separa a las clases sociales de Buenos Aires, de la imposibilidad de acción: "Encendí la luz y la lámpara parpadeó: se va a quemar, pensé, voy a quedar a oscuras". ${ }^{24}$ La narración se separa en dos mundos opuestos: luz/oscuridad, educación/superstición, riqueza/pobreza, limpieza/suciedad, movimiento social/acinesia social. No hay en este relato ningún componente sobrenatural, hay una terrible puesta en escena del determinismo social y de la imposibilidad de futuro. Se nota en este cuento cómo la urbe sí muestra cambios en su ser social, notorios en una casa o en un barrio, pero cómo al mismo tiempo hay constantes inamovibles: la ausencia de porvenir para los marginados de siempre, para un niño que ni siquiera alcanza zapatos o un nombre y que solo puede ser definido desde su característica física evidente: la suciedad.

Pero Enríquez no solo narra la pobreza: el cuento "La casa de Adela” ofrece un contrapunto en el referente económico y social. Hay de nuevo una chica como protagonista, Adela; se trata de una niña rica sometida a otro tipo de marginación, no menos terrible que la del chico sucio, también definida desde una carencia, a ella le falta un brazo, es un "monstruo", es "inquietante":

Ella era una princesa de suburbio, mimada en su enorme chalet inglés insertado en nuestro barrio gris de Lanús [...] Adela tenía un solo brazo. O a lo mejor sería más preciso decir que le faltaba un brazo. El izquierdo [...] Le faltaba desde el hombro; tenía ahí una pequeña protuberancia de carne que se movía, con un retazo de músculo, pero no servía de nada [...] Muchos otros chicos le tenían miedo, o asco. Se reían de ella, le decían monstruita, adefesio, bicho incompleto. ${ }^{25}$

21 Enríquez, Las cosas que perdimos en el fuego, 23.

22 Enríquez, Las cosas que perdimos en el fuego, 28.

23 Enríquez, Las cosas que perdimos en el fuego, 32.

24 Enríquez, Las cosas que perdimos en el fuego, 33.

25 Enríquez, Las cosas que perdimos en el fuego, 65-66. 
La historia de Adela es contada por una narradora adulta, quien recuerda, en el mundo de su infancia, la aventura con su hermano y con Adela. Tres pequeños niños, obsesionados por las historias de terror, que encuentran un escenario perfecto para su propia historia en una casa abandonada donde habían habitado un par de ancianos extranjeros. Después del uso de su imaginación, donde los niños inventan diversas narraciones, deciden finalmente entrar una noche a la casona que muestra algunos componentes que corresponden al mundo de lo grotesco e inquietante: se trata del mundo de lo cotidiano, pero que ha sido transformado de manera significativa: "deben revelarse de pronto como extrañas y siniestras las cosas que antes nos eran conocidas y familiares". ${ }^{26}$

La casa está abandonada, pero el pasto está siempre recortado, seco, sin vida; paradójicamente, la casa parece estar viva y se percibe una mezcla de dominios (casa/animal, inanimado/animado), ya que la casa "parece" un insecto: "Y la casa zumbaba, zumbaba como un mosquito ronco, como un mosquito gordo. Vibraba". ${ }^{27}$ Dentro, de noche, la casa está extrañamente iluminada por la luz del sol. Los objetos en las habitaciones parecen, a primera vista, comunes: hay un teléfono, ropa limpia apilada, un libro de medicina, pero también objetos que resultan inquietantes, no por su esencia, sino por su extraña colocación: "un espejo colgado cerca del techo, ¿quién podría reflejarse ahí?". ${ }^{28}$ Estantes ordenados repletos de uñas y dientes: "Al principio no supe lo que estaba viendo. Eran objetos chiquitísimos, de un blanco amarillento, con forma semicircular [...] Sentí que el zumbido me ensordecía y me puse a llorar. Abracé a Pablo, pero no dejé de mirar". ${ }^{29}$

El miedo en los hermanos es producido por los objetos familiares que han sido "movidos", puestos en un "orden" distinto, y que les resultan extraños porque ellos pertenecen al mundo ordenado de la infancia "normal" y "completa". Sin embargo, Adela, perteneciente al mundo de la deformidad y lo incompleto, no siente miedo sino atracción. Finalmente, esa misma noche, la casa, en sí misma deformada, devora a la pequeña Adela: "Nunca la encontraron. Ni viva ni muerta". ${ }^{30}$ La policía, en sus investigaciones, afirma que "La casa era una cáscara [...] recuerdo que los escuché decir 'máscara', no 'cáscara'. La casa es una máscara, escuché". ${ }^{11}$ ¿Máscara de qué? Probablemente del orden social: "El exterior de la casa es la máscara o la apariencia del hombre". ${ }^{32}$

No puede negarse el elemento sobrenatural involucrado en la desaparición de Adela, pero, si en el género del terror, los personajes y los acontecimientos suelen estar clasificados sobre la base del bien y del mal; en el grotesco, por su parte, la súbita irrupción ocurre de manera "inaprensible, inexplicable e impersonal. Empleando un nuevo giro podríamos decir: lo grotesco es la representación del 'id', o sea, ese id fantasmal", ${ }_{33}$ esto es, simplemente sucede, sin fuerzas divinas o demoniacas de por medio. En todo caso, lo único monstruoso en el cuento no es sino la mutilación de Adela, la casa deformada se ha quedado

26 Kayser, Lo grotesco, 224.

27 Enríquez, Las cosas que perdimos en el fuego, 71-72.

28 Enríquez, Las cosas que perdimos en el fuego, 77.

29 Enríquez, Las cosas que perdimos en el fuego, 76.

30 Enríquez, Las cosas que perdimos en el fuego, 78.

31 Enríquez, Las cosas que perdimos en el fuego, 78.

32 Jean Chevalier y Alain Gheerbrant, Diccionario de los símbolos (Barcelona: Herder, 2003), 259.

33 Kayser, Lo grotesco, 225. 
con lo que le corresponde. Lo inquietante está de nuevo en el mundo de lo familiar y lo doméstico, en una casa. Acudo al segundo epígrafe que inicia el volumen de cuentos de Las cosas que perdimos en el fuego: "I am in my own mind. / I am locked in the wrong house" de la poeta estadounidense Anne Sexton, perteneciente a For the Year of the Insane, y que acude al simbolismo de la casa como ser interior, representación de los diversos estados del alma. En ese sentido, una probable lectura del cuento indicaría que Adela no ha hecho otra cosa que encontrar su lugar de pertenencia, la casa correcta, aunque, a los ojos de los demás, otra vez la mirada del orden establecido, este hecho parezca atroz.

Prosigue en el cuento la perspectiva de la narradora al rememorar cómo su hermano Pablo, colapsado por lo acontecido, se suicida a los veintidós años, genera su propia deformidad, similar a la de su amiga de la infancia: "quedó de él ese costillar a la vista, ese cráneo destrozado, y, sobre todo, ese brazo izquierdo en medio de las vías, tan separado de su cuerpo y del tren que no parecía producto del accidente [...] parecía que alguien lo había llevado hasta el medio de los rieles para exponerlo, como un saludo, un mensaje". ${ }^{44}$

Si el cuento de "El chico sucio" se emparienta con el tono de la nota roja, "La casa de Adela" retoma el tono de la leyenda urbana: "hay que decir Adela tres veces a la medianoche, frente al espejo, con una vela en la mano, y entonces veremos reflejado lo que ella vio, quién se la llevó [...] Mi hermano [...] vio esas indicaciones e hizo ese viejo ritual una noche. No vio nada. Rompió el espejo". ${ }^{35}$ Efectivamente, si bien en este relato hay un elemento sobrenatural, este aparece para otorgar un incremento de sentido de lo "raro" o de lo otro como componentes de nuestra sociedad. El título del cuento finalmente anuncia una correspondencia: el mundo normal le resulta extraño a Adela, la rechaza, pero encuentra su lugar en el mundo de lo inquietante, hay un sentido de pertenencia, de completud: la casa de Adela. La narradora, voz adulta y racional, al recordar, afirma la existencia de la otredad: "yo sé que tiene razón. Que esta es su casa". ${ }^{36}$ Se trata nuevamente del mundo urbano, marcado por la imaginación infantil y por el gusto hacia lo fantástico de unos niños de barrio que, sin embargo, pone la crítica en las carencias de un grupo, en la anormalidad de un cuerpo, en la exclusión de un individuo de un cuerpo social que relega a lo distinto hasta hacerlo desaparecer.

La deformidad de la infancia no solo es un tema que incida en el presente de la autora, sino que se encuentra en las bases históricas de la sociedad porteña. El cuento "Pablito clavó un clavito: una evocación del Petiso Orejudo" es una reescritura de la anécdota histórica del primer asesino serial de Argentina, Cayetano Santos Godino, anécdota de principios del siglo XX que, con todos los componentes de morbo y sangre que quedaron registrados en las investigaciones policiacas de la época, subraya la deformidad moral de un pequeño asesino. El último crimen del Petiso, por el que es llevado a la cárcel, es cometido a la edad de dieciséis años, pero comienza su carrera delictiva a los siete años y suma cuatro asesinatos, siete tentativas de asesinato y siete incendios intencionales. Hijo de inmigrantes italianos, niño maltratado por su padre y marcado por la muerte de un hermano, pronto en su vida comienza a copiar el maltrato y la muerte desde su cotidianidad: sus víctimas fueron niños de entre dos y trece años.

34 Enríquez, Las cosas que perdimos en el fuego, 68.

35 Enríquez, Las cosas que perdimos en el fuego, 79.

36 Enríquez, Las cosas que perdimos en el fuego, 80. 
Este oscuro personaje es actualizado desde la profunda ironía del título del cuento ${ }^{37}$ que recupera un trabalenguas, un simple juego verbal infantil, pero que se trata del macabro método con el que el Petiso marca a la última de sus víctimas, el pequeño Jesualdo: "Así que al rato volvió a la escena del crimen. Llevaba un clavo. Lo clavó en la cabeza del niño, que ya estaba muerto [...] Quién sabe por qué, asistió al velorio del niño al que había matado. Dijo, más tarde, que quería ver si todavía tenía el clavo en la cabeza”. ${ }^{38}$

También, de manera paralela, el narrador omnisciente relata, en el Buenos Aires actual, la historia de Pablo (el mismo nombre del personaje del trabalenguas), un guía de turistas que relata los crímenes famosos ocurridos en la ciudad y al que se le aparece la figura fantasmal del Petiso. El crimen se convierte así en objeto de consumo, en espectáculo, en la marca de una ciudad signada por la violencia: "[El Petiso] no tenía más motivos que su deseo y parecía una especie de metáfora, el lado oscuro de la orgullosa Argentina del Centenario, un presagio del mal por venir, un anuncio de que había mucho más que palacios y estancias en el país, una cachetada al provincianismo de las élites argentinas que creían que sólo cosas buenas podían llegar de la fastuosa y anhelada Europa". ${ }^{39}$

Este "lado oscuro" de la Historia es actualizado desde la historia de Pablo, casado, con un hijo recién nacido, quien vive su propia crisis doméstica desatada por el nacimiento del niño: cansancio y enojos de la esposa, crianza complicada, falta de dinero, el miedo absurdo de la madre por una posible muerte del hijo, en resumen, el infierno de lo cotidiano. Ante este difícil panorama, Pablo juega con la idea, nunca realizada, de la muerte de su hijo:

La cuna inmóvil estaba oscura. Parecía el cuarto de un chico muerto, conservado intacto por una familia de duelo. Pablo se preguntó qué pasaría si el chico se moría, como parecía temer su mujer [...] Tocó la pared y se encontró con el clavo, que seguía esperando. Lo arrancó de un tirón seco y se lo metió en el bolsillo [...] Sonrió pensando en su pequeño triunfo y decidió acostarse en el sofá del living, lejos de su mujer y su hijo, con el clavo entre los dedos. ${ }^{40}$

Se encuentran analogías entre Pablo y el Petiso, en el infierno de las vidas personales, desde lo cotidiano o lo terrible, que pueden materializar, o solo pensar, el asesinato de un niño, como hecho consumado o como hecho probable. El elemento sobrenatural del relato, el "fantasma" del Petiso que se le aparece a Pablo, tiene una función más bien metafórica: "el Petiso espectral, parado a su lado, aparecía y desaparecía, temblaba, se desdibujaba, como si estuviera hecho de humo o niebla". ${ }^{41}$ Parece tratarse de un guiño: el crimen infantil como base histórica de Buenos Aires.

"El patio del vecino", por su parte, desde una voz omnisciente, presenta a una joven protagonista depresiva, alienada, que, finalmente, abrirá los ojos a una terrible realidad. Se trata de Paula, socióloga, preocupada

37 Me refiero a ironía en tanto presenta un "contraste entre valores de signo diferente [...] dos instancias en conflicto"; cf. Pere Ballart, Eironeia: La figuración irónica en el discurso literario moderno (Barcelona: Sirmio Quaderns Crema, 1994), 295-296. En este caso, se da el contraste entre el sentido lúdico que plantea el trabalenguas y el sentido criminal del último asesinato del Petiso.

38 Enríquez, Las cosas que perdimos en el fuego, 89.

39 Enríquez, Las cosas que perdimos en el fuego, 87.

40 Enríquez, Las cosas que perdimos en el fuego, 91-92.

41 Enríquez, Las cosas que perdimos en el fuego, 90. 
por el bienestar de la infancia, y que ha fungido como trabajadora social en un hogar de tránsito. Sin embargo, después de cierta irresponsabilidad en su trabajo, es cesada y debe vivir con el recuerdo de sus errores y de no haber podido ayudar a los niños marginales que estaban a su cargo; obsesionada, comienza a trastornarse: depresión, angustia, fármacos, etc.

La mudanza a una nueva casa abre la narración: es una bella casa en un barrio tranquilo, amplia, alquilada a buen precio, donde podrán, Paula y su esposo, disfrutar de una buena vida; ella podrá terminar sus estudios y, quizá, tener posteriormente un bebé: el sueño clasemediero de jóvenes profesionistas. Pronto este sueño se ve resquebrajado con la irrupción de lo inquietante: la mirada al patio del vecino, la mirada a lo otro. El patio de su casa muestra solo una fisura: "En una esquina, sin embargo, el alambre se había caído. Desde allí era posible asomarse y se alcanzaba a ver un pedazo del patio del vecino".42 Por esta fisura se cuela el mundo de lo otro: unos fuertes golpes a la puerta una noche: "como puñetazos de unas manos enormes, manos de bestia, puños de gigante", ${ }^{43}$ una presencia extraña a los pies de su cama otra noche: "Parecía un niño, pero no tenía pelo en la cabeza, se distinguía la línea clara de la calva, y era muy pequeño, delgado [...] el supuesto chico salió corriendo, pero la corrida fue demasiado veloz para un ser humano [...] Seguro era Eli porque había corrido como un gato". ${ }^{44}$

Estos eventos inquietantes son atribuidos por la protagonista a su imaginación exaltada por su reciente depresión, pero un pleito con su marido poco comprensivo, una vuelta a la soledad, alimentan su curiosidad y vuelve la mirada al patio del vecino, donde observa algo perturbador: apenas un fragmento de una pierna, de un torso, de una cadena: "un chico muy delgado y completamente desnudo; alcanzaba a verle los genitales".45 Creyendo que se trata de un niño maltratado, y abrumada por la idea de por fin salvar a un niño ("Podía salvar al chico encadenado. Iba a salvarlo"), ${ }^{46}$ irrumpe en la casa vecina aprovechando la salida del dueño de la casa, un hombre aparentemente normal en su aspecto, pero de cierta hosquedad. De nueva cuenta, como en la casa de Adela, la casa, el terreno de lo cotidiano y del mundo de la clase media, comienza a transformarse: una casa limpia, pero sin electricidad; una cocina prolija, pero maloliente: "las alacenas estaban llenas de carne podrida sobre la que crecían y se solazaban los gusanos blancos de la descomposición". ${ }^{77}$ Hay empapelado en las paredes, pero con una extraña escritura: "parecían signos pequeños, como una trama arácnida"; ${ }^{48}$ hay libros de medicina, pero con dibujos obscenos: "alguien había dibujado con birome verde una pija enorme, con espinas en el glande, y, en el útero, un bebé de grandes ojos glaucos que no se chupaba el dedo, se lo lamía con un gesto de lascivia". ${ }^{9}$

Paula huye despavorida de esa extrañeza, pero es demasiado tarde, el mundo del vecino se encuentra ahora en el de ella; el monstruoso niño invade su casa: "El chico estaba sobre la cama [...] tenía los ojos glaucos atravesados de capilares rojos y los párpados grises y grasientos, como sardinas [...] ella le vio

42 Enríquez, Las cosas que perdimos en el fuego, 133.

43 Enríquez, Las cosas que perdimos en el fuego, 133.

44 Enríquez, Las cosas que perdimos en el fuego, 137-138.

45 Enríquez, Las cosas que perdimos en el fuego, 139.

46 Enríquez, Las cosas que perdimos en el fuego, 147.

47 Enríquez, Las cosas que perdimos en el fuego, 148-149.

48 Enríquez, Las cosas que perdimos en el fuego, 149.

49 Enríquez, Las cosas que perdimos en el fuego, 150. 
los dientes. Se los habían limado y tenían forma triangular [...] El chico se llevó la gata a la boca con un movimiento velocísimo y le clavó los serruchos en la panza". ${ }^{50}$ Después de que el chico devora a la gata, le espera, a Paula, un destino similar; desde un atisbo de razón, la protagonista alcanza a preguntar: “Por qué $[\ldots]_{\text {¿ }}$ Qué sos?”; ${ }^{51}$ no hay respuesta, solo la inmovilidad de Paula: "quiso correr, pero, como en las pesadillas, le pesaban las piernas" ${ }^{52}$ Finaliza el relato con la muerte inminente de la protagonista y la ironía de ser destruida por el niño al que quería salvar. Se enfrentan los tópicos expuestos al inicio de este artículo sobre la idealización de la niñez inocente confrontada con la niñez perversa de la realidad. Para Paula, es imposible salvar algo que no desea ni puede ya ser salvado; en todo caso, la ayuda correspondería a la protagonista quien, cándidamente, termina por ser asesinada, devorada por la infancia. Como en otros relatos del volumen de cuentos, los protagonistas deben enfrentar su destino en soledad, ya que tanto las figuras maternas como las parejas o esposos son más bien indiferentes. El tema de la familia disfuncional, de la sociedad enajenada, cruza todos los relatos de Las cosas que perdimos en el fuego.

Así también el relato "Bajo el agua negra", que expone los detritus de la modernidad bonaerense y ensaya una metáfora sobre la ausencia de futuro. La mirada racional corre esta vez a cargo de una empeñosa y recta fiscal, Marina Pinat. Al igual que Paula, la protagonista de "El patio del vecino", y la narradora de "El chico sucio", la fiscal está decidida a hacer bien su trabajo, a confrontar al corrupto aparato policiaco de la ciudad y a hacer justicia a un par de chicos que han sido asesinados, arrojados al río, por unos policías. El río, usualmente símbolo del flujo de la vida, incluso liberación y purificación, ${ }^{53}$ funciona como símbolo de la acinesia y la oscuridad de la civilización; las mejores condiciones de vida de las clases adineradas, el desarrollo y la modernidad de un país solo pueden darse a costa del sufrimiento y las condiciones malsanas de los grupos sociales menos favorecidos. El río que debería ser el progreso, el Riachuelo cercano a la Villa Moreno, está detenido: "el Riachuelo no tiene casi corriente, está quieto y muerto, con su aceite y sus restos de plástico y químicos pesados, el gran tacho de basura de la ciudad. La autopsia estableció que el chico había intentado nadar entre la grasa negra". ${ }^{54}$

El componente sobrenatural aparece cuando la fiscal es visitada por una extraña adolescente quien le informa que uno de los chicos asesinados, Emanuel ("Dios está con nosotros"), ha vuelto a la Villa, que no a la vida, y desea verla: "El muerto espera soñando". ${ }^{55}$ Movida por la curiosidad y aún en busca de justicia, Marina se adentra en este mundo marginal; el otrora barrio pobre pero lleno de bullicio es ahora una tierra extrañamente muerta y silenciosa. Acude a la iglesia en busca del cura, este, antaño tan activo y esperanzado como Marina, se encuentra acabado y, desolado, se suicida frente a ella. Todo el escenario de la Villa y de la iglesia muestra turbadoras inversiones, así el mundo del lenguaje y la escritura: "Las paredes de la iglesia ya no estaban limpias. Estaban cubiertas de grafitis. De cerca, Mariana pudo ver que eran letras, pero sin sentido, no formaban palabras: YAINGNGAHYOGSOTHOTHHEELGEBFAITHR ODOG" ${ }^{56}$ También ha sido invertido el mundo de lo sagrado: "El crucifijo había desaparecido, lo mismo

50 Enríquez, Las cosas que perdimos en el fuego, 152.

51 Enríquez, Las cosas que perdimos en el fuego, 153.

52 Enríquez, Las cosas que perdimos en el fuego, 153.

53 Chevalier y Gheerbrant, Diccionario de los símbolos, 885.

54 Enríquez, Las cosas que perdimos en el fuego, 157.

55 Enríquez, Las cosas que perdimos en el fuego, 173.

56 Enríquez, Las cosas que perdimos en el fuego, 168. 
que las imágenes del sagrado corazón de Jesús y la Virgen de Luján [...] En el lugar del altar había un palo [...] Y, clavada en el palo, una cabeza de vaca". ${ }^{57}$ En este escenario, la infancia existe deformada: "Tenía un cuerpo de ocho o diez años y ni un solo diente [...] los dedos tenían ventosas y eran delgados como colas de calamar (¿o eran patas? Siempre dudaba de cómo llamarlas)", ${ }_{58}$ y casi sin lenguaje: "el chico deforme se había dado vuelta y gritaba mudo, abría la boca y gritaba sin sonido". ${ }_{59}$

Hay también una parodia de una fiesta popular, de una murga, como piensa en un inicio la fiscal. Si la fiesta popular resalta el carácter cíclico de la vida, de la regeneración, lo que hacen los habitantes de la Villa desde una falsa murga es copiar el ritual desde la muerte: "Una fila de gente que tocaba los tambores murgueros, con su redoblantes tan ruidosos, encabezada por los chicos deformes con sus brazos delgados y los dedos de molusco [...] Detrás de ellos iba el ídolo que cargaban sobre una cama [...] y lo que llevaban sobre la cama se movió un poco, suficiente para que uno de sus brazos grises cayera al costado de la cama, como el brazo de alguien muy enfermo".60 Se trata de Emanuel, el chico muerto, la parodia de Jesucristo, vencedor de la muerte, salvador de la humanidad, para afirmar lo contrario: el chico vuelve de la muerte, como Cristo, pero no para prometer una trascendencia, sino para afirmar la no vida como base de su sociedad. No es solo que el río represente el estancamiento social, sino que Mariana Enríquez propone, incluso, una vuelta al primitivismo: el no lenguaje, el retorno a ídolos primigenios, a la superstición, y va incluso más allá, a la inmovilidad y al silencio.

Emanuel es entonces un recordatorio de esos marginados que simbólicamente se niegan a morir para que el mundo vea, esa es la función de la fiscal: fungir como testigo del retroceso y de la desesperanza. Al igual que las otras protagonistas de estos cuentos, solo queda la confrontación con una realidad pavorosa que el mundo del orden y la razón se niega a ver y escuchar: "Marina corrió hacia el puente y no miró atrás y se tapó los oídos con las manos ensangrentadas para bloquear el ruido de los tambores”. ${ }^{11}$

Si bien es evidente el componente sobrenatural en este cuento, lo que se destaca es una inversión de valores: el orden establecido (Iglesia y Estado) es inoperante y el mundo de los desclasados debe crear sus propios lenguajes, rituales y modos de vida. El progreso que se esperaría de una sociedad es negado y, a cambio, se superpone la no regeneración y la deformidad como pauta social de la Villa. El cuento critica cómo el poder ilimitado del Estado, o de la industria, ha abusado de los marginales y los ha dejado sin nada material, pero también sin conocimiento y sin base espiritual, muertos. No asusta la muerte en sí misma, sino la producción hegemónica de la muerte y la deformidad.

Hay otro elemento importante que cruza los relatos y que se relaciona con el grotesco moderno: la ironía.

La muerte de Dios abre las puertas de la contingencia y la sinrazón. La respuesta es doble: la ironía, el humor, la paradoja intelectual; también la angustia, la paradoja poética, la imagen. Ambas actitudes

57 Enríquez, Las cosas que perdimos en el fuego, 168-69.

58 Enríquez, Las cosas que perdimos en el fuego, 168.

59 Enríquez, Las cosas que perdimos en el fuego, 171-172.

60 Enríquez, Las cosas que perdimos en el fuego, 172-173.

61 Enríquez, Las cosas que perdimos en el fuego, 174. 
aparecen en todos los románticos: su predilección por lo grotesco, lo horrible, lo extraño, lo sublime irregular, la estética de los contrastes [...] no es sino respuesta al absurdo: angustia e ironía. ${ }^{62}$

La exageración, la hipérbole, es un componente vital de la figuración irónica; es en el exceso que se muestran las fisuras de la modernidad:

En Las cosas que perdimos en el fuego aparece además otra marca registrada de Silvina Ocampo, la exageración. Mariana Enríquez sostiene esa mueca como un gesto heredado y sus cuentos se preguntan qué sucede más allá del límite en cualquier situación. Si las adolescentes angustiadas se tajean las muñecas, aquí se arrancan uñas, cabello y pestañas. Si la contaminación ambiental genera cáncer, aquí provocará una comunidad mutante del mejor cine Z. Las historias juegan con la tensión entre la normalidad y sus extremos en una literatura exagerada e irónica que provoca gracia y terror. ${ }^{63}$

No me parece, sin embargo, que la ironía en estos relatos provoque gracia o terror. La ironía no tiene como función sobresaltar ni formar una sonrisa, sino despertar la conciencia crítica, develar lo oculto y mostrar las fracturas de lo aparentemente completo y acabado.

Me referí antes a los variados procesos de disolución involucrados en el grotesco según Kayser: deformidad, anulación de categorías, destrucción de conceptos, mezcla de dominios, etc. Todos estos componentes se encuentran en los relatos de Enríquez: se mezcla lo sobrenatural con lo real; un niño parece más un gato o un monstruo; los niños del río crecen deformados o no tienen identidad alguna; no tienen un nombre o tienen uno que resulta una parodia; las cosas de lo cotidiano se transforman y se refuncionalizan. Una casa se transforma en un insecto que devora; el vecinito del barrio es un pequeño asesino; las creencias establecidas de un grupo se trastocan cuando irrumpe en sus vidas el mundo de la otredad y se pone en entredicho el concepto de identidad: “QQué sos?”.

Pero me interesa discutir un poco más el último elemento que destaca Kayser como constitutivo del grotesco: "la aniquilación del orden histórico". La literatura y la historia de América Latina, desde su nacimiento, han estado signadas por el tópico de civilización y barbarie. La violencia, la deformidad o lo monstruoso parecen ser, incluso, la marca cultural de América Latina vista por Occidente que desde muy temprano habló de naciones "niñas" o habitantes "monstruos". Si el Renacimiento europeo buscaba las proporciones armónicas, el descubrimiento de América, primero, sus violentas independencias y su realidad racial y social, después, afirmaban la desarmonía y la heterogeneidad. Es cierto también que la ciudad latinoamericana se convirtió en una utopía, el "sueño del orden" o el "sueño de la inteligencia", como atinadamente la llama Ángel Rama, ${ }^{64}$ sueño que, sin embargo, terminó por ser rebasado por la penosa realidad de nuestras sociedades y consumido por la propia condición jerárquica desde el que fue construido. "El sueño de la razón produce monstruos", afirmaba Goya en su célebre aguafuerte.

La civilización moderna ha concebido la Historia, y su progreso inherente, como una emancipación del hombre, como una posibilidad de futuro que lo libere, eventualmente, de la opresión y el sufrimiento. Pero,

62 Octavio Paz, "Los hijos del limo", en Obras completas, I. La casa de la presencia. Poesía e historia (México: Fondo de Cultura Económica, 2014), 341.

63 Cabral, "Frente a todos nuestros miedos", 126.

64 Ángel Rama, La ciudad letrada (Montevideo: Arca, 1998), 23. 
si como Enríquez, en la historia, se introduce el retroceso protagonizado por los marginados de siempre: pobres, deformes, explotados, enajenados y, por supuesto, los más jóvenes, los niños, los más vulnerables, la crítica a la civilización es evidente. Los marginados, el "hombre salvaje", o especificaría, el "niño salvaje", siempre ha estado en los imaginarios de la civilizada cultura occidental, como bien apunta White:

Sometimes this oppressed or repressed humanity appeared as a threat and a nightmare, at other times as a goal and a dream; sometimes as an abys into which mankind might fall, and again as a summit to be scaled; but always as a criticism of whatever security and peace of mind one group of men in society had purchased at the cost of the suffering of another ${ }^{65}$

Así, la infancia, ese marginal de los relatos de Mariana Enríquez, aparece como ambos, como amenaza y pesadilla. Son violentos o violentados, todos son producto del "progreso" moderno. Deberían ser antihistóricos, pero, por eso, la autora insiste en traerlos a la historia; esto es aún más claro con la reescritura del Petiso Orejudo, llama la atención que el primer asesino serial registrado en la historia de Argentina, con todo y sus componentes folclóricos y efectistas, sea precisamente un niño. De tal modo, Emanuel, el chico que vuelve de la muerte, reclama un lugar en el mundo, en la historia, no en el mundo fantástico de lo sobrenatural. Perturban, molestan, insisten en mostrar su suciedad, su deformidad, su perversión y sus fisuras que no son sino producto de las fisuras de la sociedad. Este "niño salvaje" vuelve y "re-muerde" la conciencia histórica, la noción de civilización y progreso; nos indica que es miembro de nuestra sociedad y no una construcción ficcional. El hecho de que estos cuentos se narren desde aparentes convenciones del terror, donde lo sobrenatural tendría que ocupar un lugar relevante, no hace sino subrayar lo contrario: no hay nada de sobrenatural en los relatos.

Es cierto que estos niños parecen asustar, en tanto no prometen un retorno a la idílica edad dorada, sino a lo irracional y salvaje. Es interesante ver cómo en dos cuentos: "El patio del vecino" y "Bajo el agua negra" se subvierte el mundo de la escritura, aquel de la "concentración, elitismo, jerarquización": ${ }^{66}$ en el primer cuento, la escritura en las paredes de la casa quiere ser un intento de organización; en el segundo, la escritura en los muros de la iglesia (YAINGNGAHYOGSOTHOTHHEELGEBFAITHRODOG) es justo lo contrario, es la afirmación del desorden, el reverso del lenguaje, el vacío. En efecto, como subraya el grotesco: todo absoluto queda derrumbado, se anula la categoría del yo, se invierte o se niega el mundo del conocimiento; todo esto no tiene como objetivo simplemente estremecer, sino plantear una posición crítica.

Enríquez marca incisivamente las cruentas realidades no solo de las tan problemáticas civilizaciones latinoamericanas, sino probablemente de toda civilización moderna, que niega o desdibuja siempre a sus sectores vulnerables. Muestra que, aunque aparentemente estos niños no tienen un lugar ni en la sociedad ni en la historia, sí lo tienen de un modo alternativo, para escándalo del poder hegemónico y de la estabilidad burguesa, y sus comportamientos, salvajes, erráticos o incómodos, no solo tienen lugar, sino hasta legitimidad.

Por supuesto que la crítica de Enríquez deja un mal sabor de boca: la "alteridad” infantil, este conjunto de niños torturados, salvajes, deformados o asesinos, la parte oscura de la sociedad está, en estos relatos,

65 Hayden White, Tropics of Discourse: Essays in Cultural Criticism (Baltimore: Johns Hopkins University Press, 1978), 180.

66 Rama, La ciudad letrada, 43. 
significada por aquellos que se supone representan la inocencia y el futuro. Pero no hay tal futuro, los niños están sujetos a un determinismo social bastante peculiar, son el síntoma de una sociedad: el chico sucio y su hermano nonato están destinados a una muerte temprana producto de la ignorancia y la superstición; el Petiso, niño maltratado, está condenado a asesinar; el niño gato a ser degenerado y salvaje; Adela a ser excluida; los chicos del agua negra a ser ladronzuelos y deformados, a ser agredidos por el poder, a ser el resultado de la sociedad caníbal moderna, enajenada por el éxito, el trabajo, la tecnología o el bienestar. Son pequeños abortados de la historia, con carencias afectivas y educativas, arrojados del "progreso".

Estos cuentos presentan la oposición entre dos grupos: la racionalidad del orden adulto y la irracionalidad de la infancia, que se miran y que cruzan el umbral que los separa. El mundo del orden caracterizado en su mayoría por mujeres protagonistas (excepción hecha de Pablo, el guía de turistas de "El Petiso Orejudo"), con poder de acción, educadas, de estratos medios o altos, y, por otro lado, la alteridad infantil. Son mundos opuestos, la invasión de un mundo a otro implica justamente el nacimiento de lo inquietante. Así, los protagonistas de estos cuentos

se encuentran del lado de la cotidianidad y la cordura, y no del otro, donde abundan la violencia y la irracionalidad [...] El miedo emerge, pues, en el espacio de la comodidad. Lo siniestro se activa cuando los y las protagonistas de estos relatos se dan cuenta de su lugar de frontera, reconociendo al otro, viéndolo y observándose a sí mismos al borde de una racionalidad distinta, de otra dimensión. ${ }^{67}$

Los personajes (una diseñadora, una socióloga, una fiscal, un licenciado en turismo, la mujer que recuerda) cruzan el umbral que separa un mundo del otro con funestas consecuencias: la frustración en la narradora de "El chico sucio"; el dolor del recuerdo para la narradora de "La casa de Adela"; la angustia para la fiscal de "Bajo el agua negra"; es, incluso, la muerte para Paula, la protagonista de "El patio del vecino"; la idea del infanticidio en el caso de Pablo. Ese cruce es, quizá, por primera vez para los personajes, un mirar lo otro. Todos ellos, más o menos representantes del centro o la razón, se asoman a la periferia o a lo inquietante. Hay una significativa inversión de valores: la inocencia corresponde a las mujeres adultas que suponen, desde su fe en el orden, la bondad, la educación y la justicia, que pueden cambiar el mundo. Esto sucede así, por ejemplo, desde la heroicidad de la fiscal, quien, incluso, lleva un arma a la Villa Moreno, ¿pero de qué sirve un arma en un barrio en el que ya todos están muertos? En el grotesco, los hechos inquietantes se dan desde el vacío, "ya no existe cosa alguna", ${ }^{8}$ no hay fuerzas divinas o demoniacas en pugna, no hay una lucha entre el bien y el mal. No hay coordenadas ni punto de orientación en el vacío.

En esta sociedad moderna, ya no es posible robar el fuego a los dioses, no hay un modelo de progreso, no hay un camino hacia adelante, pero tampoco hay un retorno al pasado: si el anhelo de la edad adulta es la vuelta a la edad de oro, a la infancia, este, si fuera posible, sería pavoroso. No hay movimiento: hay acinesia y vacío, por eso, simbólicamente, Paula, la protagonista de "El patio del vecino", cuando ve, se paraliza. Ella representa la imposibilidad de acción ante un mundo que parece transformado. Digo que "parece" transformado porque realmente no es así, no ha cambiado de pronto, sino que siempre ha sido

67 Lorena Amaro, “La dificultad de llamarse 'autora’: Mariana Enríquez o la escritura weird”, Revista Iberoamericana 85, n. 268 (2019): 806-807, https://doi.org/10.5195/reviberoamer.2019.7808.

68 Kayser, Lo grotesco, 171. 
así, como nos indica el Petiso Orejudo, solo que no lo percibíamos. La mirada previa de estos personajes es una enajenada, una que no alcanza a ver; la final, una que ve el espanto que habita en lo social.

El margen no está en la periferia, sino en el centro, es nuestro vecino. El espanto ocurre dentro del terreno de lo familiar, es la ciudad de Buenos Aires, es el río, la iglesia, el barrio, la casa de al lado o la casa propia. Todo se ha trastocado en un mundo sin bondad, sin amor, sin orden, sin ley. La intimidad entre los seres es cancelada: la mamá del chico del río ya no desea verlo; la madre del chico sucio lo entrega a un extraño culto; Pablo es excluido de su vida familiar; Adela es rechazada por la sociedad; al menor disgusto el esposo de Paula la abandona. No hay ningún vínculo profundo, ni familiar ni social: el orden en el que supuestamente debería basarse la realidad es anulado.

La autora presenta un mundo desarticulado, sin fuerzas extrañas a las que culpar, donde los protagonistas abren los ojos para mirar al otro. Es una mirada singular que asume la contradicción, la parte sombría del ser propio y de una sociedad y, sobre todo, que hace visibles a los invisibles, estos que hablan poco o que casi no hablan, pero que insisten en mostrar su existencia. Lo que Mariana Enríquez ve es a la infancia, los exhibe, los convierte en centro, los despoja de cualquier idealización y nos muestra las taras de una sociedad.

\section{Bibliografía}

Amaro, Lorena. "La dificultad de llamarse 'autora': Mariana Enríquez o la escritura weird". Revista Iberoamericana 85, no. 268 (2019): 795-812. https://doi.org/10.5195/reviberoamer.2019.7808.

Argullol, Rafael. El héroe y el único: El espíritu trágico del romanticismo. Madrid: Taurus, 1984.

Ballart, Pere. Eironeia: La figuración irónica en el discurso literario moderno. Barcelona: Sirmio Quaderns Crema, 1994.

Boix, Verónica. “Mariana Enríquez: Simpatía por los demonios”. Clarín, Revista N, 31 de enero de 2020. https:// www.clarin.com/revista-enie/simpatia-demonios_0_vE7c0RiW.html.

Cabral, María Celeste. "Frente a todos nuestros miedos: La única mujer rebelde es la que arde". Memoria Académica 7, no. 13 (2016): 125-128. http://sedici.unlp.edu.ar/handle/10915/57110.

Chevalier, Jean y Alain Gheerbrant. Diccionario de los símbolos. Barcelona: Herder, 2003.

Diccionario de la lengua latina. México, 1956.

Elias, Norbert. La civilización de los padres y otros ensayos. Bogotá: Norma/Editorial Universidad Nacional de Colombia, 1998.

Enríquez, Mariana. Las cosas que perdimos en el fuego. Barcelona: Anagrama, 2016.

Enríquez, Mariana. La hermana menor: Un retrato de Silvina Ocampo. Santiago de Chile: Universidad Diego Portales, 2014.

Kayser, Wolfgang. Lo grotesco: Su configuración en pintura y literatura. Buenos Aires: Nova, 1964.

Martinelli, Leonardo. "Mariana Enríquez: El fuego camina conmigo". El Planeta Urbano, 21 de agosto de 2020. https:/elplanetaurbano.com/2020/08/mariana-enriquez-el-fuego-camina-conmigo/.

Paz, Octavio. "Los hijos del limo". En Obras completas, I. La casa de la presencia. Poesía e historia, 299-442. México: Fondo de Cultura Económica, 2014.

Rama, Ángel. La ciudad letrada. Montevideo: Arca, 1998.

White, Hayden. Tropics of Discourse: Essays in Cultural Criticism. Baltimore: Johns Hopkins University Press, 1978. 